\title{
Contents
}

O N E Incidence of Travel 1

T w O Making Mounds 24

THREE La Caminata 48

F O U R River of Paintings 78

F I V E Land Lines 106

S I X To the Lost City 134

S E V E N Avenue of the Volcanoes 164

E I G H T Measuring the Cosmos 194

N I N E Following Pizarro 223

T E N Epilogue-Backward in Bolivia 251

A C K N O W L E D G M E T S $\quad 271$

I L L U S T R A T I O N C R E D I T S 275

I N D E X $\quad 281$ 


\section{Incidence of Travel}

In the present state of the world, it is almost presumptuous to put forth a book of travels.

John L. Stephens, Incidents of Travel in Egypt, Arabia Petroea and the Holy Land (1838)

\section{MAY 2015}

Leaving Cusco, the road to the Fiesta of the Lord of the Snows actually continues across South America to São Paulo, Brazil, but after five hours we got off the bus at Mahuayani. Usually, Mahuayani is a small settlement that straggles along the two-lane blacktop, but in late May and early June impromptu food stalls and shops sprout up at the trailhead leading to the chapel of the Lord of the Snows, or El Señor de Qoyllur Rit'i. The Fiesta de Qoyllur Rit'i has deep and tangled origins. The fiesta may have pre-Columbian roots and is certainly embedded in indigenous Andean belief and practice. ${ }^{1}$ The fiesta is a movable feast, calibrated by the reappearance of the Pleiades in the southern Andean 
night. The Pleiades mark the important beginning of an agricultural cycle, and the brightness of the constellation in mid-June is used to predict the abundance of future rains. ${ }^{2}$ Some anthropologists have suggested that Qoyllur Rit'i began as pilgrims from the eastern tropical lowlands climbed west into the high Andes. ${ }^{3}$ The ritual guardians who police the fiesta are the ukukus, young men in shaggy, black wool chaps who represent the spectacled bear (Tremarctos ornatus) that live in the cloud forests in the eastern montaña and allegedly sneak into the Andes to have sex with Quechua women. Today, Qoyllur Rit'i attracts campesinos from Quechua and Aymara villages but also large numbers of mestizos from Cusco and other Peruvian cities and towns, some New Age adherents attracted by the spectacle and sacredness, other foreign tourists, and-of course-me.

I am here because I am an archaeologist. I am interested in the ways humans mark their presence on the landscape, a broad field of inquiry into cultural landscapes and the archaeology of place, exploring "the ways in which people impart meaning - both symbolically and through action-to their cultural and physical surroundings at multiple scales and ... the material forms these meaning may take." I conduct archaeological fieldwork in South America, principally on the northern coast of Peru, but I also travel across South America to visit other sites, museums, places, and ceremonies to learn about the ways humans inscribe their presence on the earth. And that is why I am here.

I was guided to the fiesta by Angel Callañaupa Alvarez, an extremely accomplished man from Chinchero, Peru: climber, expedition guide, an activist working on problems of food security in high Andean villages, and an artist with several book credits. (Angel's early artwork was used in the seldom-seen 1971 film The Last Movie, directed by Dennis Hopper.) We were joined by Arnold, a quiet young man in his mid-twenties who studied archaeology and museum studies at the Universidad San Abad del Cusco. In Mahuayani, Angel led us to a tarp-covered kitchen run by friends from Chinchero, where we sat at rough plank tables and ate bowls of mutton and noodle soup. Great commotions swirled around us. This was the beginning of the four-day festival, and while 


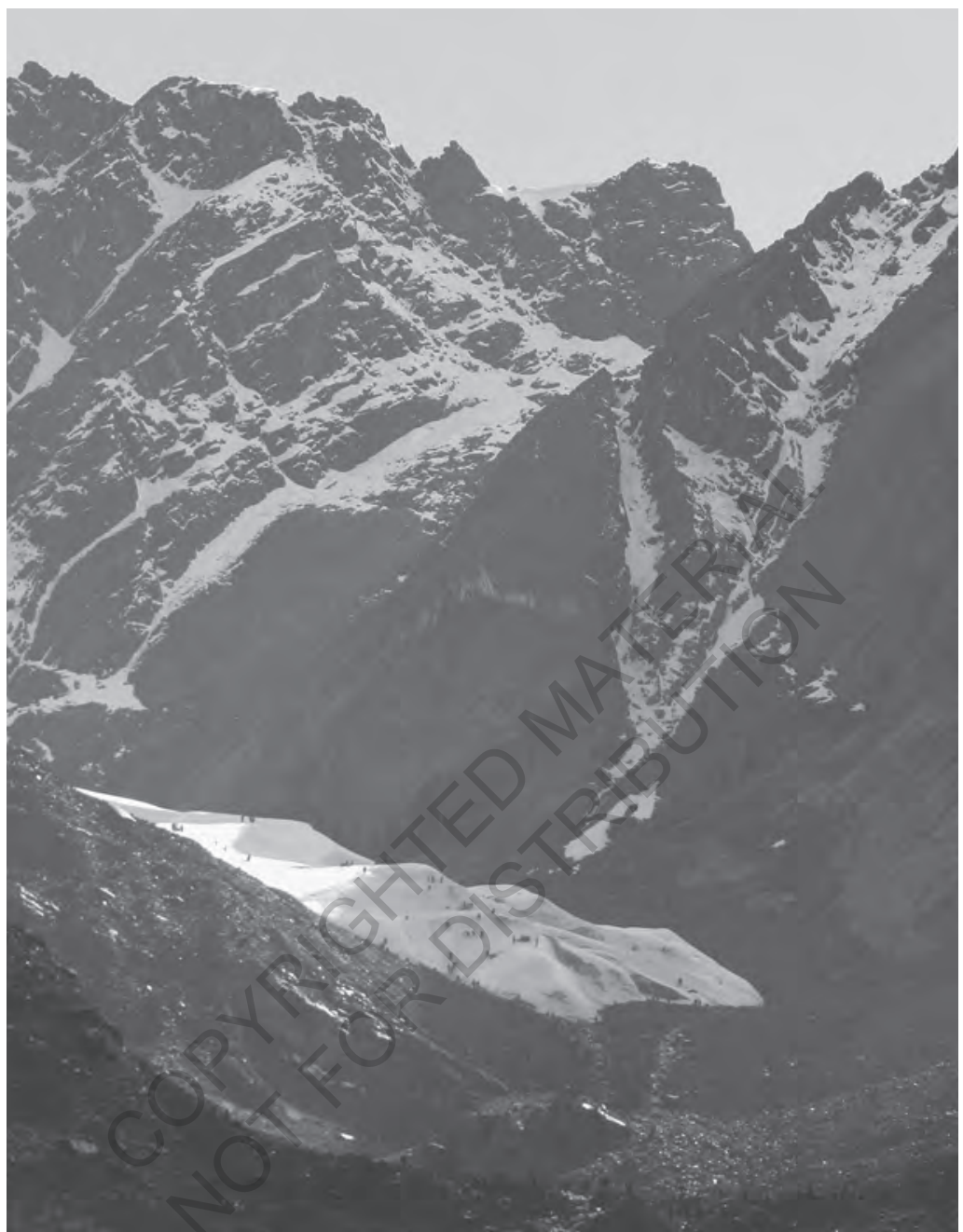

some of the kitchens and stalls were already in business, other folks were still stringing blue plastic tarps, arranging cooking hearths, and unloading goods to sell to the pilgrims. The pilgrims hike $9 \mathrm{~km}$ to over 4,300 $\mathrm{m}$ above sea level to the chapel of Qoyllur Rit'i that sits below three glaciers at the base of Mount Qulqipunku, the "Silver Gate," an $a p u$, or mountain deity, who watches over the health and well-being of people. 
Angel arranged for a packhorse to carry our gear and another horse for him to ride, and he went on to set up camp. Arnold and I began to hike, lightly burdened with water, camera, and rain gear. The sun was out, and it was about $50^{\circ} \mathrm{F}$ as we hiked. The first pitch of the trail was extremely steep. We began at 3,880 $\mathrm{m}$ and climbed higher. I was constantly out of breath. The trail leveled to a more gentle but constant grade, following a stream that flowed from distant glaciers. The hillsides flanking the trail were very steep. White llamas grazed on the slopes.

We passed clusters of vendors' shops at various points along the trail, generally at broad, flat spots or at specific kilometer posts. On the lower reaches of the trail the vendors sold food and drink, but as we climbed, more and more of the shops offered ritual items. Candles and images of Christ were for sale, but most of the items were miniature objects of desire. A principal reason for journeying to Qoyllur Rit'i is to demonstrate one's faith to the Lord of the Snow Star and to ask for help in attaining one's dreams. There were small automobiles and pickup trucks for those who desired transportation and miniature bundles of money (both Peruvian soles and US dollars) for those who wished for wealth. A variety of types of miniature real estate was offered-houses, apartment buildings, and entire hardware stores-none larger than a pack of cigarettes. If you wanted to be well-educated or improve your professional standing, you could buy miniature diplomas and certificates that would ensure you would become un maestro or un doctor. These miniatures could be purchased along the trail and carried to the shrine high above.

It took almost three hours to climb to the broad basin that held the Santuario del Señor de Qoyllur Rit'i. The basin ran northeast-southwest, edged by steep slopes, and a stream curved through it. The slopes were pocked by small rectangular terraces, camping spots associated with specific families and passed down by generations of devotees. The santuario and plaza were on the south side of the stream. A market area with more kitchens and shops bordered the stream. North of the stream, dance troupes staked out camping spots in the flat and muddy area, pitching small tents and building large cooking fires. 
We found Angel in his traditional camping spot across from the santuario on the north side of the basin overlooking the muddy flat. Angel had set up his tent, and he and Arnold set up a small tent for me as the sun went over the ridge and temperatures dropped quickly. I unpacked my sleeping bag and pad and put on warmer clothes. This was the evening of the first of four days, and the basin already held tens of thousands of the faithful. I was the only gringo I had seen so far.

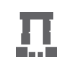

Incidence (physics): The falling of a line or anything moving in a line upon a surface.

Oxford English Dictionary

This book is about journeys and what I have learned in the course of travel about the archaeology of South America, particularly by looking at the creation of ancient cultural landscapes. My journeys are lines of movement-sometimes planned, often diverted by unforeseen eventsthat intersect with the lives and acts of other humans, past and present. Journeys are intersections, and I refer to the intersection between my travels and the material traces of other lives as "the incidence of travel." Of course, my title also plays on the titles of nineteenth-century archaeological narratives, such as John Stephens's 1838 Incidents of Travel in Egypt, Arabia Petroea and the Holy Land; his 1841 Incidents of Travel in Central America, Chiapas and Yucatán, illustrated by Frederick Catherwood; and Ephraim George Squier's 1871 Peru: Incidents and Explorations in the Land of the Inca-books that were wildly popular and widely reviewed in their day. ${ }^{5}$ A more recent connection is with the American artist Robert Smithson's 1969 project, Incidents of Mirror-Travel in the Yucatan, a work that preceded his best-known earthwork, Spiral Jetty, the coiled embankment he built on the edge of the Great Salt Lake in Utah. ${ }^{6}$ These texts and objects recurrently intersect at the creation of and inquiry into cultural landscapes, past and present. My encounters with such cultural landscapes are described in the narratives in this book. 
The following chapters intentionally braid narratives that occurred at different moments but were knotted together at a particular place. Obviously, my encounter with an archaeological site implies such an intersection, but other historical narratives and events wrap around such spaces: historical expeditions, creative and artistic reactions to places, or strands of previous archaeological investigations that produced insights into the meanings imbued in particular places. Thus, my own journeys become enmeshed with others' travels, and these are described throughout this book. These various travels by others had different motives - conquests, inquiry, explorations, settlement, diversion, devotion, escape, among others - and the tales of those journeys are interwoven with the fabrics of my own narratives.

Today, archaeological writings rarely incorporate narrative. Most archaeologists (myself included) are more comfortable writing in other genres with more stable expectations: scientific articles, excavation reports, or monographs. The very rigidity of the format of a scientific article-Introduction, Problem, Data, Methods, Results, and Discussion - is extraordinarily comforting; as a writer, one knows what comes next. Journeys are less predictable, their intersections difficult to foresee.

Journeys are barely visible in most archaeological writings — limited to an acknowledgment to a foundation for travel funds or a brief mention of the challenges involved in "implementing a research strategy"but the travel and transit are usually absent, implicit, or placed in the background. In such writings, the tale is often lost.

Yet tales of journeys are central to archaeology—and to literature in general. Nicholas Delbanco argues,

Travel writing is, I think, coeval with writing itself. We move and remember the place that we left; from a distance we send letters home ... An account of journeys taken or a report at journey's end, a message from the provinces or a dispatch from the capital: each must be written down ... One way to read the Book of Genesis is to consider that expulsion as a journey out of Eden; the long travail of Moses is a 
hunt for promised land. So too is the Aeneid a travelogue that starts in Troy and ends hard years later in Rome. "The Wanderer" and "The Seafarer" are descriptions of waterlogged distance traversed; Captain Cook and Magellan and Lewis and Clark get parsed now for their prose. Although we're not certain how widely he traveled, Avon's Bard set many of his plays abroad; it sometimes seems as though all texts we hold to be enduring ones evoke a world of wonders that at first seem passing strange. ${ }^{7}$

In Reclaiming Travel, Ilan Stavans and Joshua Ellison argue that "travel writing is related to memoir; the life story is circumscribed by a journey... Travel writing is a form of thinking aloud, with the journey as the narrative frame. The elision of travel and thought - of travel as a metaphor for thoughts — has a long history. Our English word 'theory' comes from the Greek theorin, which refers specifically to a journey beyond the city to witness an unfamiliar religious rite." ${ }^{8}$ More broadly,

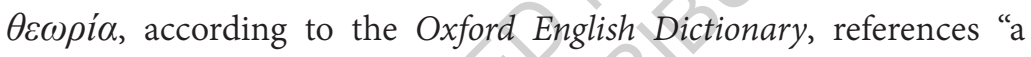
looking at, viewing contemplation, speculation, theory, also a sight, a spectacle." Travel is therefore "an enduring human enterprise. Travel is embedded in the origins of species, in our journey from African plains to every other corner of the inhabited world. It is central to our mythology and our earliest efforts to comprehend the human condition and make sense of the world around us."10

\section{II}

Many people climb to the shrine of Qoyllur Rit'i and return in a single exhausting day, carrying images of their loved ones to the shrine and returning with jugs of sanctified spring water. Qoyllur Rit'i encompasses many meanings, some of which have changed over the years. From the late 1970s until the early twenty-first century, one of the key passages in the ceremony occurred when a select platoon of ukukus climbed to the glaciers overlooking the basin, cut out huge blocks of ice, and carried the frozen relics down the mountain on their backs. Once in the basin, the blocks were chopped into smaller chunks and parceled 


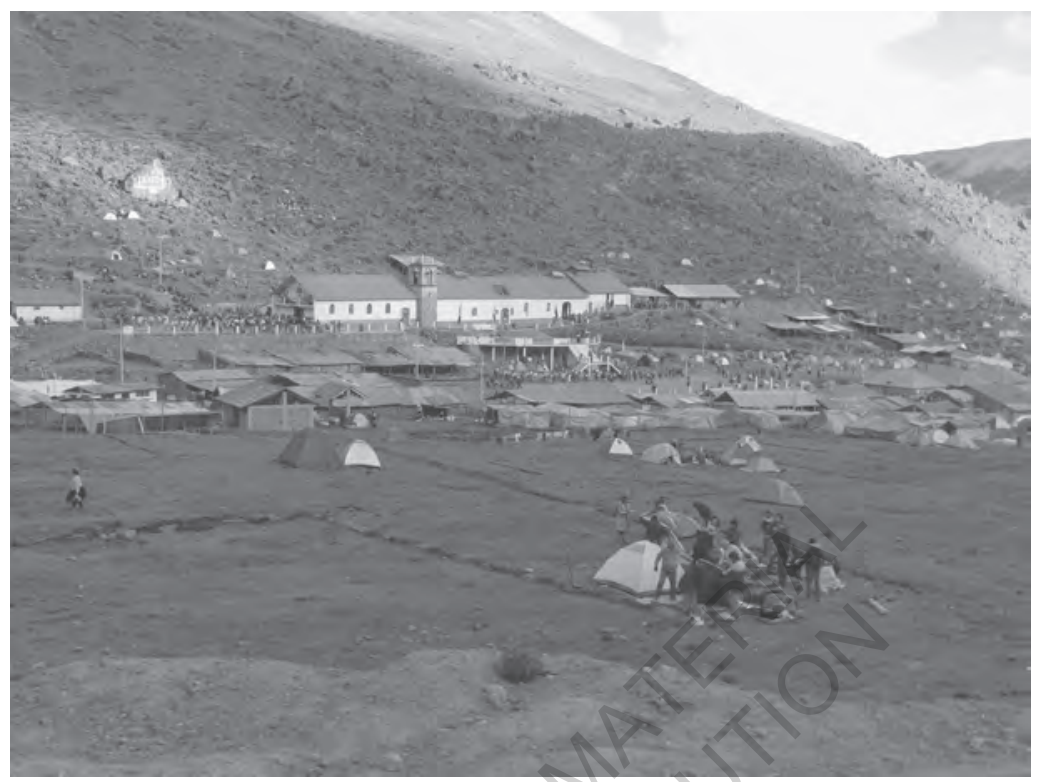

out to pilgrims from different communities who would, in turn, carry the ice chunks back to their villages where the ice was used in rituals to sustain the flow of water in their own springs, streams, and farmlands. Also, large loads of sacred ice were transported in trucks to Cusco, where the ice was displayed in the main plaza. Yet around 2009 the effects of global warming became obvious as glaciers withered in the Andes and in other high-elevation tropical zones around the world. The ukukus decided to end the ritual of collecting ice and now only allow small plastic bottles and jugs to be filled — a gallon at most — which are carried home to cure ill kinfolk after the water has been blessed in the Santuario del Señor de Qoyllur Rit'i.

The santuario is the principal religious structure, but it is not the only sacred space. The santuario is a long, narrow building with a bell tower on its north wall and a modest altar inside. The ukukus attempt to control the crush of faithful moving toward the altar to view the image of the Lord, offer a candle, and receive a sprig of white gladiola. The sheer density of the worshipers is potentially dangerous. Several years ago, the vast quantities of flaming candles — some small tapers, others 
thick wax cylinders as long as your leg-posed a fire hazard, and one child was asphyxiated in the smoke. As we shoved toward the altar in the santuario, the crowd became anxious and people began to shout in alarm. The first acrid smell of panic mixed with the reverence of the worshippers. I glanced at the altar from a distance and slid out a side door. I was no longer among the faithful.

\section{II}

Just as the earliest human stories are tales of journey-the discovery of a waterhole or the encounter with an enemy-similarly, the earliest archaeological writings were entwined with narratives of travel: accounts of discoveries, mishaps of travel, and encounters with modern people living in ancient places. Consider the opening paragraphs of Monumenta Britannica by the British archaeologist John Aubrey (1626-97), describing his first encounter with the Neolithic dolmens of Avebury:

TO THE READER

I was inclined by my genius, ${ }^{11}$ from my childhood to the love of antiquities: and my fate dropped me in a country most suitable for such enquiries.

Salisbury Plain, and Stonehenge I had known from eight years old: but, I never saw the country about Marlborough, till Christmas 1648 ... Charles Seymour and Sir William Button, met with their packs of hounds at the Grey Wethers ... The chase led us (at length) through the village of Avebury, into the closes there; where I was wonderfully surprised at the sight of those vast stones: of which I had never heard before: as also at the mighty bank and graff [ditch] about it: I observed in the enclosures some segments of rude circles, made with these stones; whence I concluded, they had been in the old time complete. ${ }^{12}$

Here, in this early archaeological observation, we see some of the basic elements in archaeological narratives: journey, encounter, surprise, observation, and inference. 
Nearly a century before Aubrey's journey to Avebury, John Leland (1503-52) — the English poet, bookman, and antiquarian - traveled across England to consult monastic libraries, journeys that led him to note the presence of other antiquities. Bearing the authorization of King's Antiquary, Leland crisscrossed England and Wales, as he noted in the opening lines of The Laboryouse Journey and Serche of John Leylande for Englandes Antiquitees addressed to Henry VIII:

Amonge all the nacions, in whome I have wandered, for the knowledge of thynges

(moste benygne soueraygne)

I haue founde nene so negligent and vntoward, as I haue found England in the due serch of theyr auncyent hystores, to the syngulare fame and bewtye therof. ${ }^{13}$

Unfortunately, Leland died of madness before completing his magnum opus, which was only published in the late nineteenth century. Yet the themes of arduous travel, the entrancing beauty of things, and the modern world's shameful neglect of the past—all of these echo with my experience as an archaeologist six centuries later.

Narrative — and especially tales of travel—dominated archaeological writings well into the late nineteenth century, became less prominent in the mid-twentieth century, and thereafter rendered nearly invisibleexcept when archaeologists share their experiences over beers. And yet, as Rosemary Joyce has written, "Archaeology is a storytelling discipline from its inception in the field or lab." ${ }^{14}$

The dominant genres of archaeological writing - the report and the essay-often overlook the journeys that led to archaeological insights, not only the physical journeys but the intellectual transits, the passages through modern cultures, and the movement from ignorance to insight. Since these early texts, narrative has been gradually eliminated from archaeological writings, especially from technical reports in which the author's voice - and, often, presence - is erased from the text.

The act of writing is integral to archaeology. Joyce adds: "Writing pervades archaeology, from the creation of field notes and other records 
of research observations to the creation of informal and formal presentations. Archaeology is continually being scripted and rescripted from previous fragments, both in these writing practices and in its other embodied activities." ${ }^{\prime 15}$

The following narratives of encounter have several specific goals, while I intentionally avoid other matters. First, they present my own journeys in South America to archaeological sites and landscapes with a particular emphasis on place-making in the past and present. I am primarily interested in cultural landscapes and the creation of place in the archaeological record, and this is true whether I have written on the creation of ancient architecture, the development of cultural landscapes, the construction of sacred space, the prehistory of home, or the social adaptations by hunters and gatherers in the deserts of northern Baja California. ${ }^{16}$ My own journeys to these "sites" - a term intriguingly stripped of valence-were also inquiries into how they were transformed into "places" by the people who once lived there, but they also became "places" to me through the act of journeying. I do not claim to fully understand the original meanings of these places for their inhabitants: I would never be so bold, as I am acutely aware of my ignorance. Yet by seeing these places with my own eyes, I have gained a deeper appreciation of, a greater empathy about, these landscapes and the people who created them.

Second, the narratives of my journeys interweave with historical accounts, archaeological reports, and other sources of information that create an intellectual landscape of contexts and relevancies. In many cases, I planned a specific journey because I was intrigued by a particular site or ceremony; in other cases, I blundered upon places whose significance I only later understood. In every case, the information and insights of others-whether explorers, archaeologists, artists, ethnographers, soldiers, or writers-deepened my experience of travels in South America.

Third, I have tried to write this book in a way that will engage a general reader. For this reason, I intentionally emphasize the narrative line, avoid unnecessary jargon, and direct the reader to scholarly references 
modestly consigned to endnotes. I believe archaeologists must write for a broader and sophisticated reading audience. A few archaeologists do. ${ }^{17}$ For example, the prolific Brian Fagan has written scores of books on archaeology and related topics, such as climate change, food, and pets. The classical archaeologist Ian Morris has written four books exploring the broad sweep of human history to understand patterns of conflict and cohesion among modern societies. The biblical archaeologist Eric H. Cline wrote an outstanding book about the complex factors leading to the collapse of the eastern Mediterranean and Egypt during the Bronze Age. In the United Kingdom, the archaeologist, farmer, and novelist Francis Pryor has written numerous books about British archaeology and landscape, as well as being a principal in the Time Team television series. These archaeologists write for academic and popular audiences, and I apologize in advance for overlooking others of whom I am not aware. But note: the Society for American Archaeology has over 7,000 members, and it is estimated that 11,000 archaeologists work in the United States alone. When the most widely read and reviewed books about New World archaeology were the excellent 1491: New Revelations of the Americas before Columbus (2005) and 1493: Uncovering the New World Columbus Created (2011) by science journalist Charles Mann or journalist Marilyn Johnson's Lives in Ruins (2015), there should be room for an archaeologist to actually write about what we archaeologists actually do: uncover and retrieve forgotten elements of the past and incorporate them into the consultable record of the human experience.

Finally, the following chapters are not narratives of self-discovery. With the extraordinary popularity of Elizabeth Gilbert's Eat, Pray, Love: One Woman's Search for Everything across Italy, India, and Indonesia, an expectation has emerged that travel narrative necessarily involves personal self-discovery or, as an editor who wished to remain anonymous explained to me, "the emotional journey ... along the way." Frankly, I do not travel to discover myself; I don't think I am interesting. My vision is outward and I travel, as John Leland did, "for the knowledge of thynges." 


\section{ח}

The sun went over the ridge and the temperature dropped. I was in my sleeping bag by 6:30 p.m., exhausted. The midwinter night was cold and long at Qoyllur Rit'i. I slept fully dressed with thermal long-johns, pants, long-sleeved T-shirt, flannel shirt, parka, gloves, stocking cap, and my stocking feet shoved into the pockets of a down vest in the bottom of my sleeping bag. I shook in the cold. I propped up my upper body to help me breathe. I was in the sleeping bag for nearly twelve hours, and I dozed for less than six hours of shivering, air-gasping sleep.

The fiesta continued throughout the night. Many pilgrims departed from Mahuayani after nightfall—climbing the trail in the darkness, bearing raised pennants on upright poles, and following dancers and musicians in transitory pools of sound and light. All night, other groups danced and paraded in the plaza on the east side of the santuario. The bands played bass and snare drums, clarinets and trumpets, and often saxophones. In the plaza, the dancers had choreographed routines, their phrasings signaled by a choreographer's blasts on a police whistle. The music reverberated through loudspeakers the size of refrigerators. Fireworks and mortar shots blasted throughout the night, echoing across the basin. The sounds of the fiesta ebbed slightly at around 3 a.m. but never silenced.

I crawled out of my tent around 6 a.m. The sky was thinly silvered. My tent was needled with hoarfrost, as was the flat basin below. I stumbled about on the uneven terrain in frozen boots. Around 20,000 to 30,000 pilgrims had arrived overnight and camped in the basin, their small tents covered in sheets of cobalt blue plastic. Sometime during the night, a Quechua couple had rigged a makeshift tent right below my terrace. Their "tent" was simply a 2 -m-wide flat sheet of plastic anchored with stones and no higher than the undercarriage of a Volkswagen. They had arrived in last night's darkness, made camp, and now lay in front of me softly snoring in a thick mantle of heavy woolen blankets. I almost tumbled down onto them when I squirmed out of my tent. 


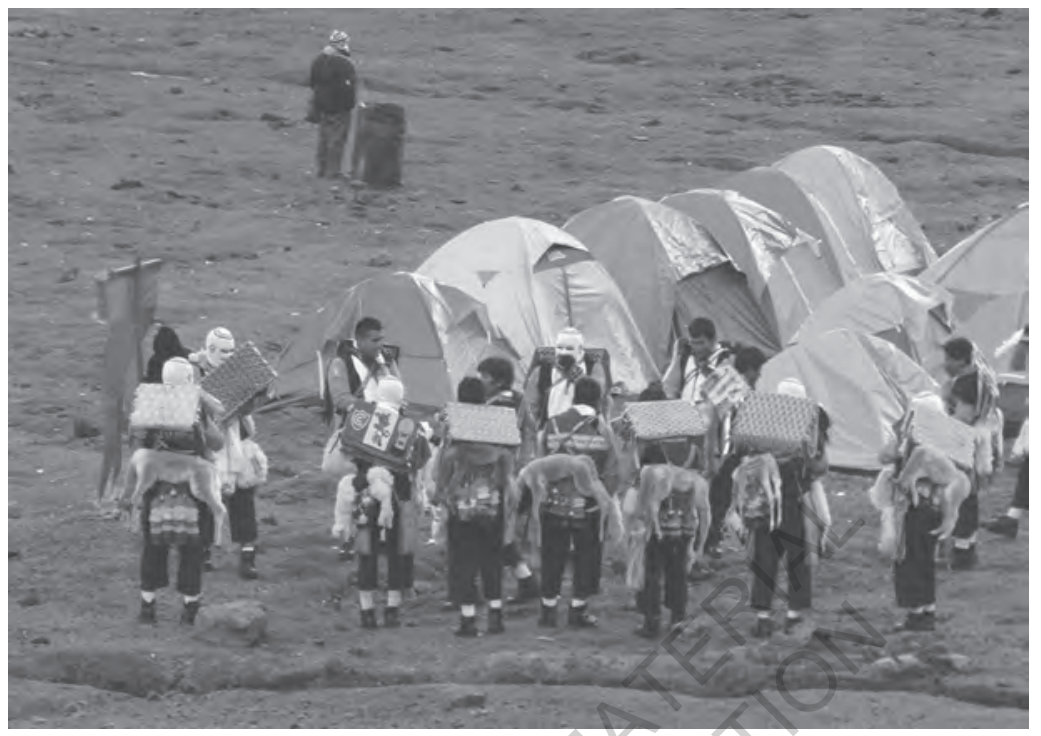

The dance troupes stirred, arranging capes and masks, tightening drum-skins. As the sun rose over the glaciered ridges, the dance troupes prepared their first songs of the day, which they played to the sun-facing east to the Inti rather than toward the santuario. Gestures like these made me wonder whether Catholicism was a thin veneer over indigenous practice or whether-more probably-such questions were meaningless and misguided. Rather than remnants of past traditions or impositions of Catholicism, it is probably more reasonable to think of these gestures as ongoing and evolving attempts by people trying to understand and represent their place in the world.

And this is certainly true of the area above the santuario that consists of las piedritas and el Banco del Señor. The zone is called las piedritas (the little rocks) because the vendors of dreams stack small chunks of shale into lot boundaries, create small skyscrapers and buildings, or mark the areas where they sell other miniatures. The notion is that if you buy a miniature, your wish will be granted. Most of the vendors are women, members of a sellers' association all wearing identical dayglow orange vests. Ritual miniatures are used in various ceremonies in the southern Andes, such as in the Alasitas Fiesta in Bolivia, in which 


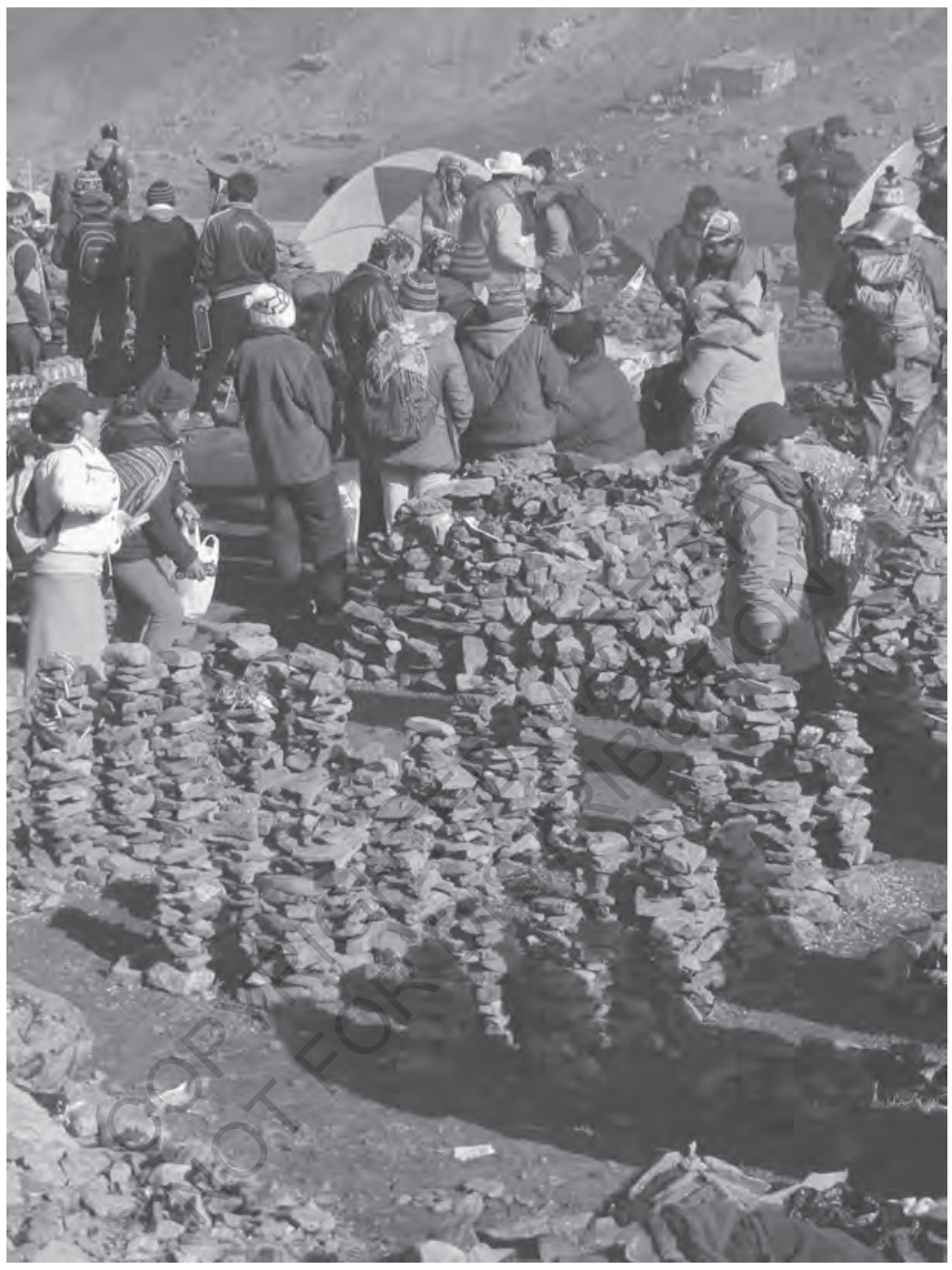

small objects of desire-small stacks of dollar bills, miniature automobiles, or tiny jumbo jets - are used to ask for wealth, vehicles, or a journey to Miami from Ekeko, the god of abundance, prosperity, and fecundity. ${ }^{18}$ This practice may have originated in prehistory, with miniature projectile points found in hunting-and-gathering sites dating to 5,000 to 4,400 years ago. ${ }^{19}$ Over the last decades, versions of Ekeko have 
become more widespread in Argentina and Chile, although I didn't see any images of Ekeko himself at Qoyllur Rit'i; the miniatures were seen throughout the las piedritas area.

According to Angel, these miniatures are relatively recent at Qoyllur Rit'i. In past decades, small stones were the sole tokens; and they represented only llamas, alpacas, and sheep. Instead, I heard a young man offer, like a circus midway huckster, "Parcels! Parcels! I am selling lots in New York City worth $\$ 100,000$, but you can have one for only a single sol"- - about thirty cents.

Once you have bought your miniature or certificate of ownership, you go to the Banco del Señor.

Just downslope from las piedritas, the Banco del Señor is a building about $12 \mathrm{~m}$ long, with a plaza and altar to the Virgin on the east side and three bank teller windows-Caja 1, Caja 2, Caja 3-on the long north wall. The banco is a recent construction, according to Angel, built to enclose and contain a large boulder, a wak' $a .{ }^{20}$ In the Andes, the Quechua term wak'a (also spelled "huaca" or "guaca") is broadly applied to sacred places and things, objects of veneration that are often natural landforms with special significance. This particular waka was a large boulder venerated by young girls and single women, who gave offerings of thread and candles and asked the wak'a for aid in finding a husband, for good health, or in other requests. Recently, the wak'a was expropriated by enclosing the stone within the walls of the banco, physically incorporating the boulder into the altar for the Virgin Mary, who is adored and honored by pilgrims in the small plaza on the east side of the building. But on the north side of the building, the ukukus control the crowds lined up before the bank tellers' windows. Having purchased your miniature deed to a $\$ 100,000$ lot in New York for one sol, you can go to the Banco del Señor, be attended at one of the tellers' windows, and make an additional payment of a few soles to the Virgin to help ensure that the deal comes true.

Other dreams are sought in the las piedritas zone. Next to a large boulder, a man wearing a cheap version of a priest's stole and holding a plastic Coke bottle of "holy water" shouted, "Okay! Who wants to 
get married?" A raucous clutch of teenagers shoved one boy to the front, laughing- "Here! He does! He has a girlfriend!"—but the boy scrambled back into the crowd. Across the crowd, an embarrassed girl looked at the ground. The "priest" bantered in a rapid and slang-filled mix of Spanish and Quechua that I couldn't really follow, but the crowd roared with laughter. The priest stepped toward the crowd, spraying the onlookers with surprising streams of holy water. Convulsions of laughter. "Okay! Okay! Who wants to be married?" the priest demanded. More laughter and confusion. Finally, a middle-aged couple stepped forward. Based on their street clothes, they were not campesinos but from Cusco or another town. The couple stood in front of the priest. An assistant appeared with a selection of copper wedding rings of different sizes slotted into a wooden box lined with cheap velveteen. The couple and the ring assistant fumbled a bit, finding rings the correct size. The priest shouted, "And now - who will be the godfather and godmother?" Another middle-aged couple came forward and stood on each side of the betrothed. "Bueno," the priest began and launched into another sermon for the next five minutes, a monologue that convulsed the onlookers. Whenever hilarity flagged, the priest squirted holy water. The mass concluded with a hand wave of benediction. The couple kissed, signed a "marriage certificate," and paid the priest. The copper rings were twisted from fingers and replaced in their slots in the velveteen-lined box. The newlyweds headed downhill to validate their wedding at the Banco del Señor.

Angel observed that a spatial and moral axis runs through the Fiesta of Qoyllur Rit'i, from the Santuario upslope to the Banco del Señor and las piedritas. Downslope, the Santuario del Señor, the secondary chapel flickering with masses of candles, and plazas filled with dancers and musicians comprise a solemn, sacred, collective, and reverent zone, policed by ukukus armed with llama whips. Uphill, the banco and las piedritas are ironic areas, focused on everyday wishes, individual and irreverent. Along this gradient, there are different gestures and enactments of faith, marked by different material traces - what I, as an archaeologist, think of as diverse artifacts, features, and sites. 
Each year when the Pleiades reappear in the southern Andes, this high cirque is reanimated by human actions and beliefs, anchoring a broad variety of gestures, dreams, and desires. In turn, these human hopes and actions are enacted in this specific place on this particular and resonant segment of terrain, and in that process landscape is imbued with meaning.

\section{$\Pi$}

The following chapters explore different aspects of place-making in ancient South America, regions and times past that I encountered in my journeys between 1981 and 2015. Chapter 2 discusses a common class of archaeological monument-human-made earthen mounds-and considers how these apparently simple masses may have complex constructions and subtle associations, insights I gained during excavations in far northern Peru. Chapter 3 describes a ritual procession I joined in southern Ecuador, walking through a landscape that was imbued with the sacred and made sacred through human actions. Chapter 4 is an account of a journey I made to Patagonia to see a remarkable example of prehistoric rock art, a beautiful human creation in a featureless, wind-scoured landscape. This is followed by an essay (chapter 5) about how people have marked their presence by inscribing lines on the land, including such famous examples as the Nasca lines but also literally hundreds of other examples of geoglyphs across South America, ancient and modern, including in the Atacama Desert where I journeyed to see the longest poem in the world. Chapter 6 is based on my trek in the mountains of northern Colombia-two-and-a-half days on foot, two-and-a-half days on mule-to visit a remote site associated with the Kaaga people and their ancestors, a culture of surpassing sophistication and complexity whose priests are entrusted with defending the Earth. Moving south to Ecuador (chapter 7), I describe a beautiful region periodically destroyed by fierce volcanic eruptions, cataclysmic events that obliterated ancient societies and became encoded in myth and legend. This region of Ecuador is also the principal location for 
the following chapter (chapter 8), which explores the different ways Western scientists and Andean astronomers approached the measurement of the cosmos. Chapter 9 describes a journey on "the beautiful road," the Qhapaq Nan, the roadway the Incas created to unify their empire-that inadvertently became the avenue of conquest for the expedition led by Francisco Pizarro and the chaos and destruction that occurred in its aftermath. The last chapter serves as an epilogue, exploring the ways archaeologists and others see the past as more stable and coherent than it was seen by the people who made place across the length of South America.

A final note: throughout this book, sections within chapters are separated by a trapezoidal symbol, as below. This is based on a common map symbol used in South America, which stands for a tampultambo, a way station along the Inca road. By extension, its presence in the following pages marks a waypoint on the reader's journey through this text.

\section{I}

At Qoyllur Rit'i the morning dawned cold and clear, but by 9 a.m. it looked like rain. Fog rose up the valley, and the eastern sky weighed with water. I asked Angel if we needed to buy plastic sheets from the vendors who wandered among the pilgrims, selling meters of tarp from long blue rolls. Angel thought it wasn't necessary as the rain would freeze and quickly slide from our backpacking tents. The rain came at around 10:30 a.m., and we crawled back into the tents. As Angel predicted, the rain immediately froze on the tent's rip-stop nylon, but the walls slumped under the rime. Inside the tent, I batted the walls so the ice slid off the fly. After an hour or so, the rain paused and we got out and surveyed the situation. The broad flat below us was a muddy bog. Other pilgrims were climbing out to check their tents, call for more blue plastic, and try to get dry. In the plaza by the Santuario del Señor, the bands and dancers never halted.

Angel looked east at the clouds above the glaciers and predicted "viene el nevado," and the first snowflakes fell as we climbed back into 


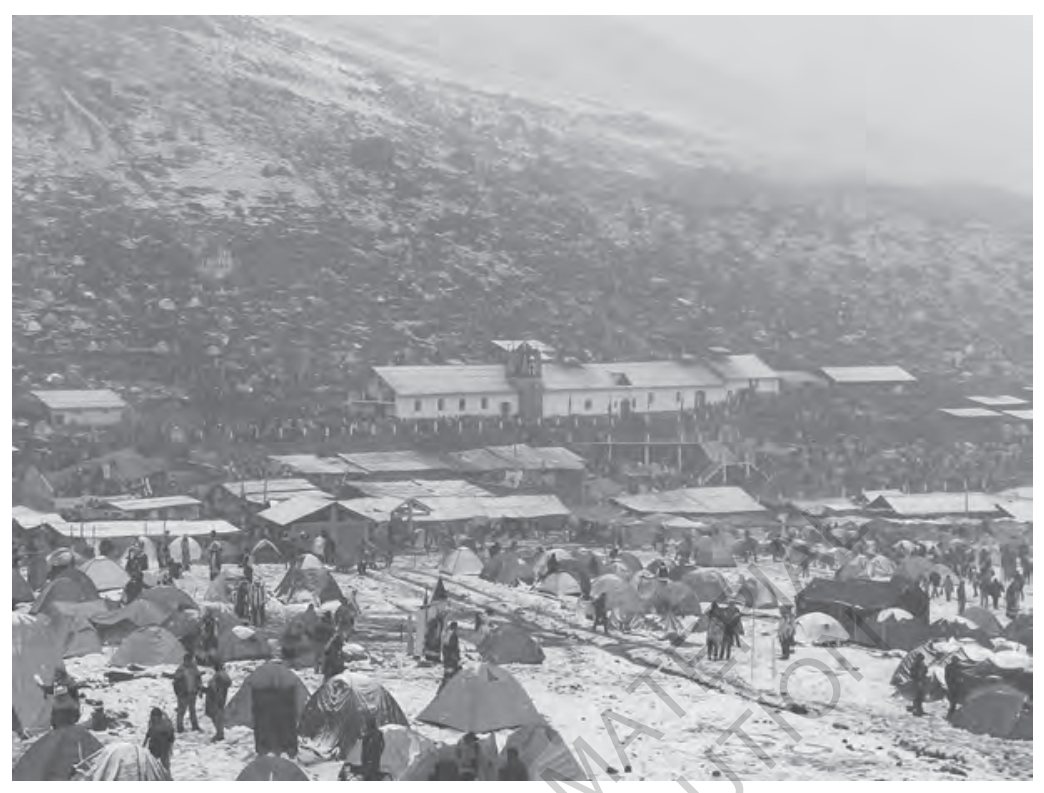

the tents. Over the next half hour, two to three inches of snow fell. The tent walls pressed to my face and seemed to make breathing that much harder. The snow stopped and we climbed out of our tents once again. Angel and I discussed the situation. Since it had snowed at noon, he was fairly certain it would snow again during the night, and he didn't know if the tents would bear the weight. The prospect of a long winter night sleeping in snowdrifts did not appeal to us. We decided to break camp and head down.

We left around 2 p.m. and passed large crowds of pilgrims and tourists heading up to Qoyllur Rit'i. The pilgrimage troupes danced up the mountain. The tourists ranged from large parties of a dozen people to single, ill-equipped travelers. One large group of gringo tourists with a trekking group, some on horseback, was accompanied by arrieros who drove pack mules that carried luggage, gear, and bundles of firewood. As I passed them going downhill, they looked at me quizzically, as if to ask why I was leaving when the major events were just beginning. Angel looked back at the clouds and remarked at how dark and foreboding they appeared. Despite this, the mountain path was thronged 
with travelers on their way to the Santuario del Señor de Qoyllur Rit'i, drawn by faith or curiosity to this specific valley in the southern Andes transformed by ancient practices and modern rituals into a complex and deeply human place.

\section{NOTES}

1. There are differences in scholarly opinion about when the Fiesta de Qoyllur Rit'i originated. Randall argued that it was originally an Inca fiesta; see Robert Randall, "Qoyllur Rit'i: An Inca Fiesta of the Pleiades: Reflections on Time and Space in the Andean World," Bulletin de l'Institut Français d'études andines 11, no. 1-2 (1982): 37-81; Robert Randall, "The Mythstory of Kuri Qoyllur: Sex, Seqes, and Sacrifice in Inka Agricultural Festivals," Journal of Latin American Lore 16, no. 1 (1990): 3-45. In contrast, Salas Carreño notes that the earliest historical account mentioning the pilgrimage dates to the 1780 s and the current fiesta became more developed in the 1930s; see Guillermo Salas Carreño, "Acerca de la antigua importancia de las comparsas de wayri ch'unchu y su contemporánea marginalidad en la peregrinación de Quyllurit'i," Antropologica 28 (2010): 67-91; Guillermo Salas Carreño, "The Glacier, the Rock, the Image: Emotional Experience and Semiotic Diversity at the Quyllurit'i Pilgrimage (Cuzco, Peru)," Signs and Society 2.S1 (2014): S188-S214. For historical images of the fiesta, see pictures by the great Cusqueño photographer Martin Chambi (1891-1973), who photographed the fiesta in 1931 and 1935; see Martín Chambi: Photographs, 1920-1950 (Washington, DC: Smithsonian Institution Press, 1993), 105-6.

2. Benjamin Orlove, John Chiang, and Mark Cane, "Forecasting Andean Rainfall and Crop Yield from the Influence of El Niño on Pleiades Visibility," Nature 403 (January 6, 2000): 68-71.

3. Randall, Bulletin de l'Institut Français, 54.

4. Maria Nieves Zedeño and Brenda J. Bowser, "The Archaeology of Meaningful Places," in The Archaeology of Meaningful Places, edited by Brenda J. Bowser and Maria Nieves Zedeño, 1-14 (Salt Lake City: University of Utah Press, 2009), 5.

5. For example, see excerpts from Edgar Allen Poe's reviews of Stephens's book, as discussed by Roscoe Hill, "John Lloyd Stephens and His American Book," The Americas: A Quarterly Review of Inter-American Cultural History 6, no. 2 (1949): 197-207.

6. See Robert Smithson: The Collected Writings, edited by Jack Flam (Berkeley: University of California Press, 1996).

7. Nicholas Delbanco, "Review: Anywhere out of This World: On Why All Writing Is Travel Writing," Harper's Magazine 309, no. 1852 (September 2004): 91-92.

8. Ilan Stavans and Joshua Ellison, Reclaiming Travel (Durham, NC: Duke University Press, 2015), 29. 
9. Ibid., 29.

10. Ibid., 99.

11. Here, Aubrey uses "genius" in its classical Roman sense: "the tutelary god or attendant spirit allotted to every person at his birth," Oxford English Dictionary.

12. John Aubrey, Monumenta Britannica, annotated by Rodney Legg, 2 vols. (Sherborne, Dorset, UK: Dorset Publishing Company, 1980 [1665-93]), part I: 17-18, accessed March 11, 2016, https://archive.org/details/laboryousejourn0obalegoog.

13. See also Matthew Johnson, "Commentary: Archaeology as Travel and Tourism," International Journal of Historical Archaeology 15 (2011): 298-303.

14. Rosemary Joyce with Robert Preucel, Jeanne Lopiparo, Carolyn Guyer, and Michael Joyce, The Languages of Archaeology: Dialogue, Narrative, and Writing (Oxford: Blackwell, 2008), 17.

15. Ibid., 7.

16. For example, Cultural Landscapes in the Prehispanic Andes: Archaeologies of Place (Gainesville: University Press of Florida, 2006); The Prehistory of Home (Berkeley: University of California Press, 2012).

17. The archaeologist Brian Fagan has spent most of his career writing for a non-archaeological reader, having written more than forty-six books and numerous articles about archaeology and related topics; for a full list and other information, see http://www.brianfagan.com. Ian Morris's books for a general audience include Why the West Rules - For Now: The Patterns of History, and What They Reveal about the Future (New York: Farrar, Straus, and Giroux, 2010); The Measure of Civilisation: How Social Development Decides the Fate of Nations (Princeton: Princeton University Press, 2013); War! What Is It Good For? Conflict and the Progress of Civilization from Primates to Robots (New York: Farrar, Straus, and Giroux, 2014); Foragers, Farmers, and Fossil Fuels: How Human Values Evolve (Princeton: Princeton University Press, 2015). Among his many books, Eric H. Cline's 20141177 BC: The Year Civilization Collapsed (Princeton: Princeton University Press, 2014) was widely reviewed. In the United Kingdom, Francis Pryor has written numerous books about British archaeology and landscape; see https:// pryorfrancis.wordpress.com. A recent effort to extend archaeologists' reach to a broader readership was initiated by Brown University's Joukousky Institute for Archaeology and the Ancient World with a competition titled "Archaeology for the People: The Joukowsky Institute Competition for Accessible Archaeological Writing"; nearly 150 articles were submitted, and a selection of the ten best articles is forthcoming.

18. Michèle Cros and Daniel Dory, "Apprivoiser le marché: Éléments d'interprétation des alacitas en Bolivie," Journal des anthropologues: Association française des anthropologues 98-99 (2004): 171-201; Jim Weil, "From Ekeko to Scrooge McDuck: Commodity Fetishism and Ideological Change in a Bolivian Fiesta," Ideologies and Literature 4, no. 1 (1989): 7-29; Jim Weil, “The Articulated Peasant: Household Economies in the Andes," American Anthropologist 105, no. 2 (2003): 444-45. 
19. Mark Aldenderfer, "Continuity and Change in Ceremonial Structures at Late Preceramic Asana, Southern Peru," Latin American Antiquity 2 (1991): 227-58.

20. For a recent discussion, see the volume edited by Tamara Bray, The Archaeology of Wak'as: Explorations of the Sacred in the Pre-Columbian Andes (Boulder: University Press of Colorado, 2015). 